\title{
Effects of interferon alfa and gamma on human uveal melanoma cells in vitro
}

\author{
I de Waard-Siebinga, W M Creyghton, J Kool, M J Jager
}

\begin{abstract}
Background-Uveal melanoma is a tumour with a high incidence of metastasis and a high mortality rate. Additional therapies to obtain a better local control or an effective treatment of metastases are necessary. Interferons may be applied. Methods-The effects of human interferon alfa and gamma on proliferation and expression of immunologically important molecules of human uveal melanoma cells in vitro were studied. A propidium iodide assay was used to determine proliferation and immunostaining with monoclonal antibodies was applied to detect changes in antigen expression on two primary uveal melanoma cell lines, Mel 202 and 92-1.

Results-Interferon alfa inhibited proliferation of cell line 92-1 at a concentration of $50 \mathrm{IU} / \mathrm{ml}$, but had no effect on cell line Mel 202, while interferon gamma inhibited growth of both cell lines. Only interferon gamma had a visible effect on cell morphology. With respect to the immunomodulatory effects, interferon alfa increased monomorphic HLA class I expression, but did not affect HLA class II expression. Interferon gamma induced not only HLA class I but also class II expression. The effects on HLA expression were locus-specific with the strongest. effects observed for HLA-B and DR products. Small differences were observed with respect to the susceptibility of two different melanoma cell lines to antiproliferative effects and to modulation of antigen expression.
\end{abstract}

Conclusion-The effects of interferon alfa and gamma on human uveal melanoma cells in vitro suggest a potential role of these cytokines in the treatment of patients with uveal melanoma. In particular, the immunomodulatory effects of these cytokines in vitro imply that treatment of patients with these cytokines might stimulate a beneficial antimelanoma immune response in vivo.

(Brf Ophthalmol 1995; 79: 847-855)

Ophent of

University Hospital

Leiden, the

Netherlands

I de Waard-Siebinga

W M Creyghton

$\mathrm{J}$ Kool

M J Jager

Correspondence to: Itte de Waard-Siebinga, $M D$, Department of

Ophthalmology, University Hospital Leiden, PO Box

9600, 2300 RC Leiden, the Netherlands.

Accepted for publication 24 April 1995 reported, especially in the treatment of haematological malignancies. ${ }^{1-3}$ IFNs may also be of importance in the therapy of high risk cutaneous melanoma ${ }^{45}$ although the results are variable. However, the exact mechanisms of the anti-tumour activities of IFNs (immunomodulatory or antiproliferative) are still unknown and it is impossible to predict which patients may benefit most from IFN treatment. With regard to the potential immunomodulatory effect, IFNs are able to modulate the expression of cell surface molecules such as HLA class I and class II antigens. ${ }^{6}$ These molecules are essential in the generation and regulation of an effective antitumour immune response by $T$ cells, since tumour specific antigens can only be recognised by $T$ lymphocytes when the antigens are presented in the groove of HLA molecules. Since allele specific binding of tumour specific antigens has been reported - for example, for human cutaneous melanoma, ${ }^{7-9}$ differences in the level of different HLA molecules might be important in the development of effective antitumour immune responses.

In a previous study, we determined the expression of HLA class I and II antigens on frozen tissue sections of uveal melanoma. Differences in the level of expression of different HLA molecules were observed: HLA-B antigens showed a lower level of expression than HLA-A. ${ }^{10}$ This low level of allele specific HLA class I expression might effect a putative anti-tumour immune response in vivo. Based on these results we hypothesised that HLA molecules on uveal melanoma cells in vitro might be sensitive to IFN mediated upregulation of expression.

More is known about the effects of IFNs on other types of cultured human malignant cells. ${ }^{11-14}$ For human cutaneous melanoma cells, for instance, the effects of IFNs on cell proliferation, cell differentiation, and antigenic phenotype have been studied. ${ }^{15-18}$ In summary, these studies revealed the following: (1) inhibition of cell proliferation by both type I IFN (IFN- $\alpha$ and IFN- $\beta$ ) and type II IFN (IFN- $\gamma$ ); (2) cellular dedifferentiation by type II IFN; and (3) enhancement of HLA class I expression by types I and II IFNs and enhancement of HLA class II expression by type II IFN. Information on human uveal melanoma cells is still lacking, and it may be helpful to predict the potential effect of the clinical application of different interferons.

In the present study, therefore, we investigated the in vitro effects of type I IFN (recombinant IFN- $\alpha$ ) and type II IFN (recombinant IFN- $\gamma$ ) on cell proliferation, HLA antigen expression, and cell morphology of human uveal melanoma cells.

\section{Materials and methods}

CELL LINES

Two human uveal melanoma cell lines, Mel 
202 and 92-1, were used. The cell line Mel 202 was kindly provided by Dr B Ksander ${ }^{19}$ (Schepens Eye Research Institute, Boston, USA). The cell line 92-1 was established from a uveal melanoma in our own laboratory. ${ }^{20}$ Tumour material was obtained from a 76-yearold patient with an ocular melanoma with extensive infiltration in the orbit. Tumour tissue was made into a cell suspension and grown on 3T3 mouse fibroblast cells as a feeder layer. The resulting tumour cells have been passaged approximately 45 times during more than 2 years. The in vitro doubling time is 58 hours. The cells were maintained as monolayers in petri dishes in RPMI 1640 medium (Gibco, Paisley, UK) supplemented with penicillin and streptomycin $(100 \mathrm{IU} / \mathrm{ml}$ and $100 \mu \mathrm{g} / \mathrm{ml}$, Gibco), L-glutamine ( $3 \mathrm{mM}$, Gibco) and fetal bovine serum ( $10 \%$, Hyclone, USA). Cell cultures were incubated at $37^{\circ} \mathrm{C}$ in a humidified atmosphere of $5 \%$ carbon dioxide in air.

All cells of both cell lines showed expression of the melanocyte associated antigens as determined in immunohistology with monoclonal antibodies HMB-45 and NKI-beteb.

\section{CYTOKINES}

Recombinant human interferon gamma, rIFN$\gamma$ (specific activity $2 \times 10^{7} \mathrm{IU} / \mathrm{mg}$ protein) was kindly provided by $\operatorname{Dr} S$ Osanto (Leiden University Hospital, the Netherlands). Recombinant human interferon alfa-2b, rIFN$\alpha$ (specific activity $1.66 \times 10^{8} \mathrm{IU} / \mathrm{mg}$ protein) was kindly supplied by Essex BV, Schering Plough, the Netherlands.

\section{CELL PROLIFERATION}

For the proliferation experiments, $1.25 \times 10^{5}$ cells and $10^{5}$ cells of the cell lines $92-1$ and $\mathrm{Mel}$ 202 , respectively, were seeded in $6 \mathrm{~cm}$ petri dishes and allowed to attach over a 24 hour period. The cultures were then incubated with 50 or $500 \mathrm{IU} / \mathrm{ml}$ of rIFN- $\alpha$ or rIFN- $\gamma$. The control cultures consisted of cells incubated with standard medium without rIFN- $\alpha$ or rIFN- $\gamma$. Between day 1 and day 7 after administration of the cytokines, detached cells were collected from the supernatants, and attached cells were harvested with a $0.01 \%$ trypsin solution (trypsin 1:250, Na/EDTA $0 \cdot 2$ $\mathrm{mg} / \mathrm{ml}$, and dextrose $1 \mathrm{mg} / \mathrm{ml}$; Difco, USA).

Table 1 Monoclonal antibodies

\begin{tabular}{lllll}
\hline & & \multicolumn{2}{c}{ Dilutions } & \\
\cline { 3 - 4 } Antibody & Specificity & Cytochemistry & FACS analysis & Reference \\
\hline W6/32 & HLA, A, B, C & $1: 20$ & $1: 40$ & 23 \\
BBM1 & B2-microgl & $1: 2$ & $1: 4$ & 24 \\
HCA2 & HLA-A & $1: 600$ & $1: 600$ & 25 \\
HC10 & HLA-B & $1: 600$ & $1: 600$ & 26 \\
BB7.2 & HLA-A2, Aw69 & $1: 20$ & $1: 40$ & 28 \\
GAP-A3 & HLA-A3 & asc & $1: 1$ & $\ddagger$ \\
116/5/28 & HLA-Bw4 & $1: 80$ & $1: 160$ & 29 \\
SFR-8-B6 & HLA-Bw6 & asc & $\dagger$ & 30 \\
B8.11.2 & HLA-DR & $1: 20$ & $1: 40$ & 31 \\
SPV-L3 & HLA-DQ & $1: 2500$ & $1: 5000$ & 32 \\
B7/21.2 & HLA-DP & $1: 200$ & $1: 400$ & 33 \\
Leu4 & CD3 & $\dagger$ & $1: 100$ & \\
\hline
\end{tabular}

^Dilutions of the monoclonal antibodies as used for cytochemistry and FACS analysis respectively (asc $=$ ascites, $\dagger=$ not used, $\ddagger$ source: Dr K Gelsthorpe, NTBS, Sheffield).
Both cell samples from each petri dish were stored together at $4^{\circ} \mathrm{C}$ until use in the proliferation assay at day 9 . The experiments were performed in triplicate dishes. Cell proliferation was determined in a non-radioactive propidium iodide assay (PI assay) as described by Bruning and Kardol, ${ }^{21}$ and Schanz et al ${ }^{22}$ based upon the measurement of total nuclear DNA. Briefly, $100 \mu$ l of each sample was pipetted in a 96 well $\mathrm{U}$ bottom tray and $50 \mu \mathrm{l}$ of a lysing staining quenching mixture (LSQM) containing $14.9 \%$ Triton-X-100 (8\%; Fluka, Switzerland), 14.9\% propidium iodide (1 $\mathrm{mg} / \mathrm{ml}$; Sigma, USA), 0.9\% LeitzQuencher (diluted 1/4; Leitz, German), 69.3\% EDTA buffer (4.9\% sodium EDTA in distilled water, $\mathrm{pH} 7 \cdot 0$ ) was added. After 4 hours of incubation the trays were read by an automated fluorescence microscope (Leica-Patimed, Germany) which measures photometer values $(\mathrm{mV})$ to determine the number of PI stained nucleated cells. The last wells of each tray contained LSQM medium only and served as background control.

\section{CELL MORPHOLOGY}

In order to evaluate the effects of interferons on cell morphology, photographs of the cultures were taken with an inverted microscope (Axiovert 10, Zeiss, Jena, Germany) equipped with phase contrast lenses, after 2 days of incubation.

\section{IMMUNOCYTOCHEMISTRY}

For immunocytochemistry uveal melanoma cells were seeded in six well plates in numbers of $1-3 \times 10^{5}$ per well in a total volume of $1.5 \mathrm{ml}$ of standard medium. Twenty four hours after seeding, cells were incubated with IFN- $\alpha$ or rIFN- $\gamma$ at concentrations of 50, 200, and 500 $\mathrm{IU} / \mathrm{ml}$. Control cultures consisted of cells incubated without the administration of cytokines. After 2 days of incubation the cells were harvested by trypsinisation $(0.01 \%$ trypsin). Immediately after harvesting, the cells were attached to glass slides using a Shandon cytocentrifuge. These cytospin preparations (cytospots) were then air dried and fixed for 10 minutes in acetone at room temperature and stored at $-70^{\circ} \mathrm{C}$ until required for immunocytochemistry. The cytospots were stained with monoclonal antibodies using a three step indirect immunoperoxidase technique.

Briefly, the cytospots were incubated with the specific antibody in the appropriate dilution for 1 hour, followed by incubation for 30 minutes with peroxidase conjugated rabbit anti-mouse antiserum and 30 minutes with peroxidase conjugated swine anti-rabbit immunoglobulin (Dakopatts, Glostrup, Denmark). Between each incubation, the cytospots were washed in phosphate buffered saline (PBS) for 5 minutes. For visualisation of the immunoreactivity, the slides were incubated for 7 minutes with 3amino-9-ethyl-carbazole at $0.2 \mathrm{mg} / \mathrm{ml}$ (Sigma, St Louis, MO, USA) in $0.1 \mathrm{M}$ sodium acetate buffer (pH 5), containing $0.05 \%$ hydrogen peroxide. Finally, the preparations were 


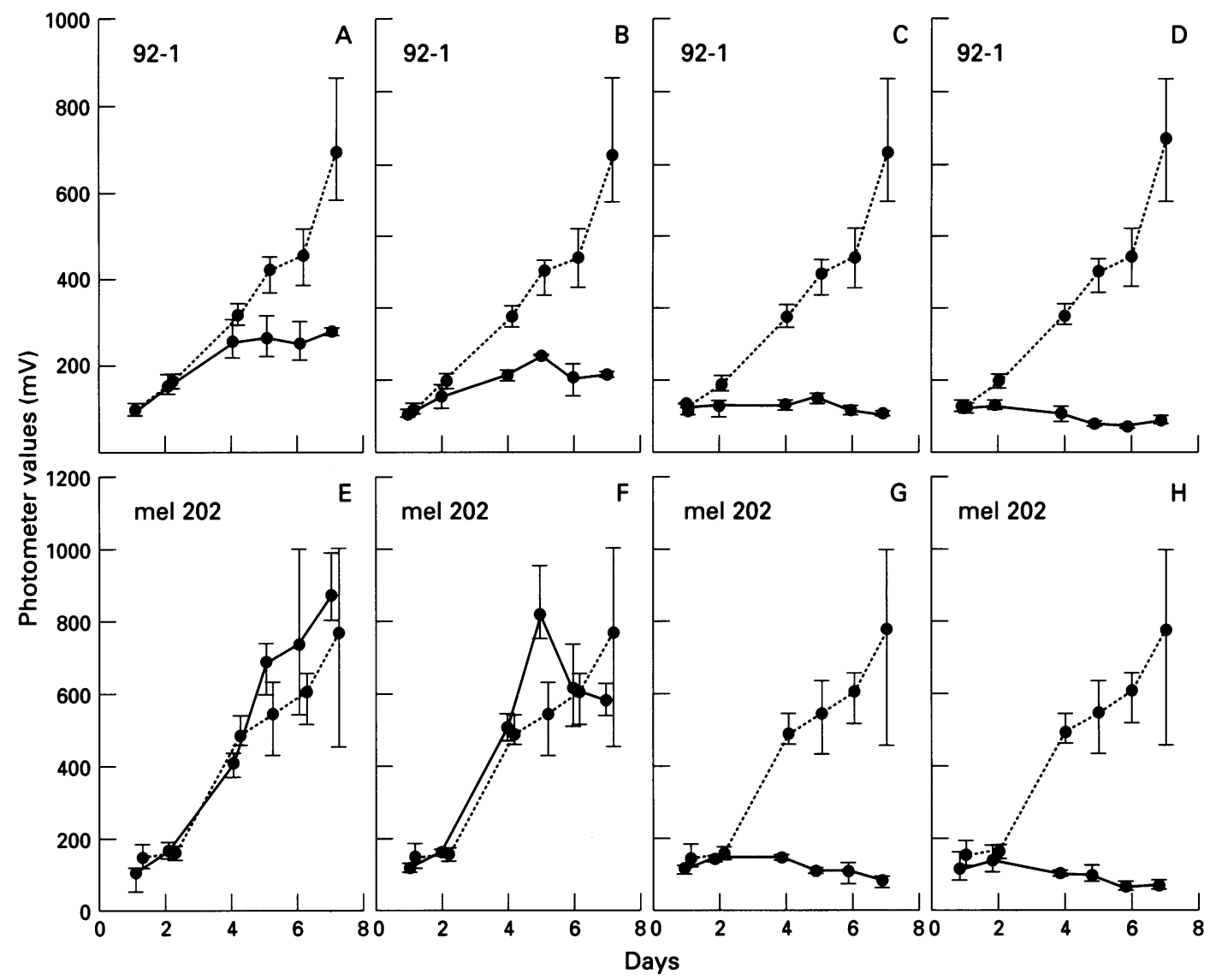

Figure 1 Effects of IFN- $\alpha$ and IFN- $\gamma$ on the proliferation of the human uveal melanoma cell lines 92-1 (A-D) and Mel $202(E-H)$. After 1-7 days of incubation with either control medium or IFN- $\alpha$ or IFN- $\gamma$ at different concentrations, the total amount of DNA was determined in a propidium iodide assay as described in Materials and methods. The photometer values $(\mathrm{mV})$ correlate with the total amount of DNA and so do the number of cells. In all figures the data points represent the mean of three independent measurements and the total range is depicted by bars. The proliferation curves of the untreated controls are represented by the broken lines. $(A)$ and $(E)$ Effects of $50 \mathrm{IU} / \mathrm{ml} \mathrm{IFN}-\alpha ;(B)$ and $(F)$ effects of $500 \mathrm{IU} / \mathrm{ml} \mathrm{IFN}-\alpha ;(C)$ and $(G)$ effects of $50 \mathrm{IU} / \mathrm{ml} \mathrm{IFN}-\gamma ;$ and $(D)$ and $(H)$ of $500 \mathrm{IU} / \mathrm{ml} \mathrm{IFN}-\gamma$.

counterstained with Mayer's haematoxylin, dehydrated, and coverslipped with Kaiser's glycerol gelatin. Negative controls consisted of incubations replacing the primary antibodies by PBS/bovine serum albumin (BSA) $1 \%$. The monoclonal antibodies used in this study are listed in Table 1. All slides were examined by light microscopy, magnification $\times 400$. Immunoreactivity was scored by counting the number of positive cells of a total of 500 cells in each cytospot. Intensity of the staining was coded as follows: - no positive cells, + majority of positive cells staining weakly, ++ majority of positive cells staining intermediately, +++ majority of positive cells staining strongly.

\section{FLUORESCENCE ACTIVATED CELL SORTER}

ANALYSIS

For fluorescence activated cell sorter (FACS) analysis uveal melanoma cells were seeded in either $6 \mathrm{~cm}$ or $9 \mathrm{~cm}$ dishes. On day 1 after seeding, the cells were incubated with $200 \mathrm{IU} / \mathrm{ml}$ rIFN- $\alpha$ or rIFN- $\gamma$, either alone or in combination. All experiments were performed in duplicate dishes and control cultures consisted of untreated cells. After 2 days of incubation, the cells were harvested by trypsinisation to make single cell suspensions $(0 \cdot 01 \%$ trypsin). After washing in PBS, $0.5-1 \times 10^{5}$ cells were incubated with $100 \mu l$ dilutions on the primary monoclonal antibodies in PBS/BSA $1 \%$ for 1 hour (the monoclonal antibodies are listed in Table 1). After incubation with the primary antibody, the cells were washed in PBS/BSA $1 \%$ followed by incubation with a 1:50 dilution of fluorescein isothiocyanate conjugated rabbit anti-mouse immunoglobulin (RAM/FITC; Dakopatts, Denmark) for 30 minutes. Both incubations were performed at $4^{\circ} \mathrm{C}$. The fluorescence measurements were performed with a FACScan II (Becton Dickinson, San Jose, CA, USA). Background fluorescence was determined by incubating the cells with a nonreactive primary antibody (anti-CD3) and RAM/FITC.

\section{STATISTICS}

For statistical analysis of the proliferation data the Mann-Whitney test was used. Statistical analysis of the FACS data was performed using the LYSIS II software (Becton Dickinson).

\section{Results}

EFFECT OF rIFN- $\alpha$ AND rIFN- $\gamma$ ON CELL PROLIFERATION

The effects of IFN- $\alpha$ and IFN- $\gamma$ on cell proliferation of two uveal melanoma cell lines (92-1 and $\mathrm{Mel} 202$ ) were determined in a propidium iodide assay (Fig 1), and for each day the photometer values of the IFN treated cells were 


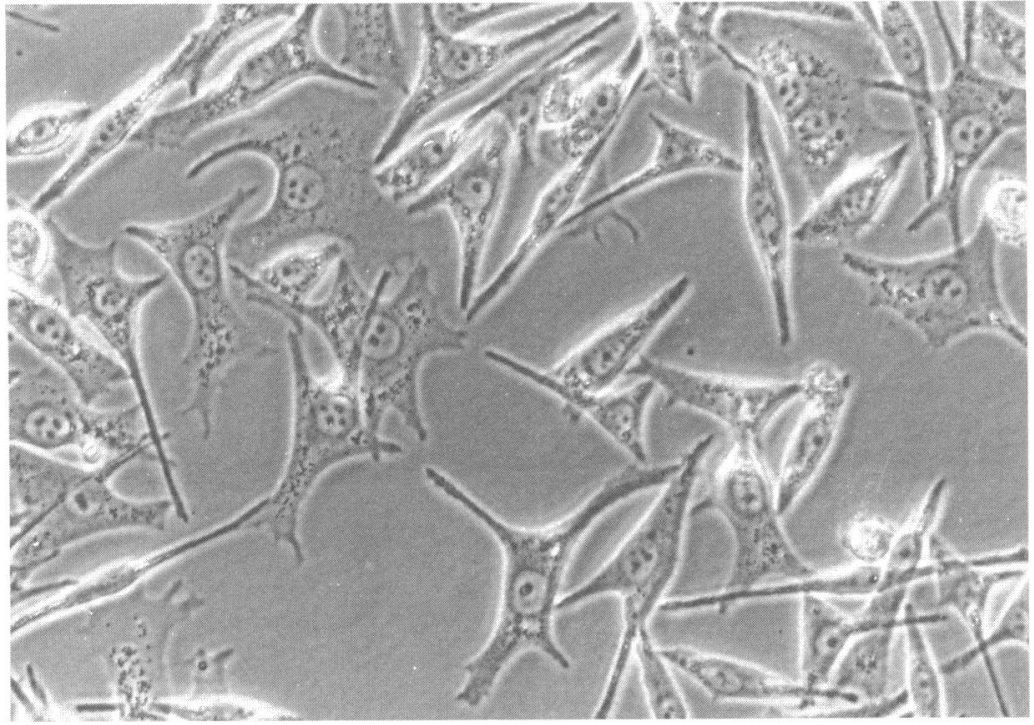

Fig $2 A$

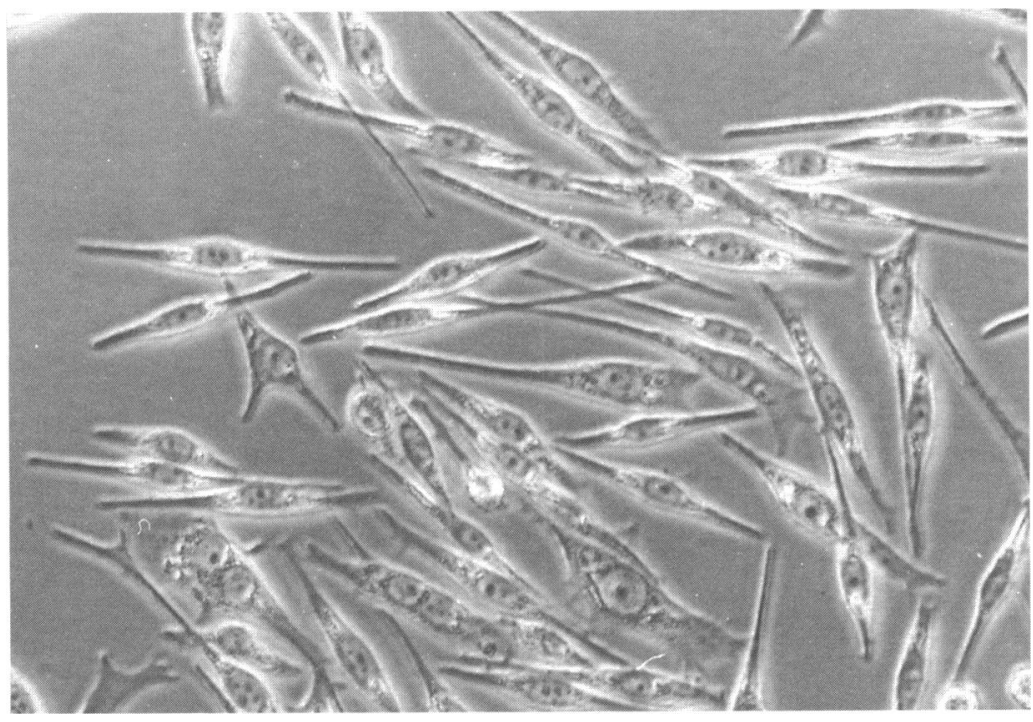

Fig $2 B$

Figure 2 Effect of IFN- $\gamma$ on cell morphology (cell line 92-1). Photomicrographs were taken after 2 days of incubation. (A) Control cells. (B) Cell culture treated with IFN- $\gamma$ $(50 \mathrm{IU} / \mathrm{ml})$ showing significantly more bipolar cells. Original magnification $\times 200$.

compared with those of untreated cells. Treatment of the 92-1 cells with rIFN- $\alpha$ at a concentration of $50 \mathrm{IU} / \mathrm{ml}$ led to a significant decrease in cell proliferation starting at day 5 after incubation $(p=0.05$; Fig $1 \mathrm{~A})$, while treatment with a higher dose of rIFN- $\alpha(500 \mathrm{IU} / \mathrm{ml})$ already had an effect on day $4(p=0 \cdot 05$; Fig $1 B)$. rIFN- $\gamma$ totally inhibited proliferation of the 92-1 cells at both concentrations (Figs 1C and 1D).
In contrast with the 92-1 cells, proliferation of the Mel 202 cells was not affected by treatment with rIFN- $\alpha$ (Figs $1 \mathrm{E}$ and $1 \mathrm{~F}$ ). On the other hand, rIFN- $\gamma$ totally inhibited proliferation of the Mel 202 cells in a similar fashion as it inhibited growth of 92-1 cells (Figs $1 \mathrm{G}$ and $1 \mathrm{H}$ ).

EFFECT OF rIFN- $\alpha$ AND rIFN- $\gamma$ ON CELL MORPHOLOGY

IFN- $\alpha$ did not significantly change cell morphology, while application of IFN- $\gamma$ induced visible changes in the uveal melanoma cells: with IFN- $\gamma$ the relative number of bipolar cells increased in comparison with the number of multipolar cells (Fig 2).

\section{EFFECT OF IFN ON HISTOCOMPATIBILITY} ANTIGENS

The effect of rIFN- $\alpha$ and rIFN- $\gamma$ on expression of HLA class I and II molecules was studied with two techniques. At first, locus and allele specific monoclonal antibodies were applied to cytospins of two uveal melanoma cell lines (92-1 and Mel 202) to determine the percentage of staining cells with and without the presence of interferon. Since our experiments showed very high staining levels (even at low concentrations of both types of interferon), we subsequently applied another technique that is, FACS analysis, to study the effect of the combination of the two interferons used.

\section{EFFECT OF rIFN- $\alpha$ AND rIFN- $\gamma$ ON ANTIGENIC PROFILE AS DETERMINED BY IMMUNOCYTOCHEMISTRY}

\section{HLA class I expression}

Strong expression of the non-polymorphic determinants of the HLA class I antigens (MoAb W6/32) and of $\beta_{2}$ microglobulin (MoAb BBM1) was observed on $100 \%$ of the cells of both cell lines (data not shown). The immunocytochemical study on the effects of interferons was extended to locus and allele specific HLA class I expression, as determined by monoclonal antibodies directed against HLA-A, A2, A3, B, Bw4, and Bw6, respectively (Table 1). These polymorphic antigens were selected because of their high frequency in the population. We were able to determine the HLA class I type of the donor of cell line 92-1 retrospectively, and this was $\mathrm{A} 2, \mathrm{~A} 3, \mathrm{~B} 51$

Table 2 HLA class I expression and modulation by interferons after 2 days of incubation as determined by immunocytochemistry

\begin{tabular}{|c|c|c|c|c|c|c|c|c|c|}
\hline \multirow[b]{2}{*}{$\begin{array}{l}\text { Treatment } \\
(I U / \mathrm{ml})\end{array}$} & \multicolumn{5}{|c|}{ Cell line 92-1 } & \multicolumn{4}{|c|}{ Cell line Mel 202} \\
\hline & $\begin{array}{l}H L A-A \\
\text { int } / \% \%^{\star}\end{array}$ & $\begin{array}{l}H L A-A 2 \\
\text { int } / \%\end{array}$ & $\begin{array}{l}H L A-A 3 \\
\text { int } / \%\end{array}$ & $\begin{array}{l}H L A-B \\
\text { int } / \%\end{array}$ & $\begin{array}{l}H L A-B w 4 \\
\text { int } / \%\end{array}$ & $\begin{array}{l}H L A-A \\
\text { int } / \%\end{array}$ & $\begin{array}{l}H L A-A 3 \\
\text { int } \% \%\end{array}$ & $\begin{array}{l}H L A-B \\
\text { int } / \%\end{array}$ & $\begin{array}{l}\text { HLA-Bw4 } \\
\text { int } / \%\end{array}$ \\
\hline $\begin{array}{l}\text { Control } \\
\text { rINF- } \alpha 50 \\
\text { rINF- } \alpha 200 \\
\text { rINF- } \alpha 500\end{array}$ & $\begin{array}{l}++/ 100 \\
++/ 100 \\
+++/ 100 \\
+++/ 100\end{array}$ & $\begin{array}{l}+/ 69 \\
++/ 100 \\
++/ 100 \\
++/ 100\end{array}$ & $\begin{array}{l}++/ 98 \\
++/ 99 \\
+++/ 100 \\
++/ 100\end{array}$ & $\begin{array}{l}++/ 99 \\
+++/ 100 \\
+++/ 100 \\
+++/ 100\end{array}$ & $\begin{array}{l}-/ 0 \\
+/ 98 \\
++/ 100 \\
++/ 100\end{array}$ & $\begin{array}{l}+/ 93 \\
++/ 100 \\
++/ 100 \\
++/ 100\end{array}$ & $\begin{array}{l}++/ 100 \\
++/ 100 \\
++/ 99 \\
++/ 99\end{array}$ & $\begin{array}{l}+/ 1 \\
+/ 49 \\
++/ 80 \\
++/ 89\end{array}$ & $\begin{array}{l}-/ 0 \\
-/ 0 \\
+/ 3 \\
++/ 10\end{array}$ \\
\hline $\begin{array}{l}\text { rINF-g } 50 \\
\text { rINF-g } 200 \\
\text { rINF-g } 500\end{array}$ & $\begin{array}{l}+++/ 100 \\
+++/ 100 \\
++/ 100\end{array}$ & $\begin{array}{l}++/ 100 \\
++/ 99 \\
++/ 100\end{array}$ & $\begin{array}{l}++/ 100 \\
+++/ 100 \\
+++/ 100\end{array}$ & $\begin{array}{l}+++/ 100 \\
+++/ 100 \\
+++/ 100\end{array}$ & $\begin{array}{l}++/ 100 \\
++/ 100 \\
++/ 96\end{array}$ & $\begin{array}{l}++/ 100 \\
++/ 100 \\
++/ 100\end{array}$ & $\begin{array}{l}++/ 99 \\
++/ 98 \\
++/ 98\end{array}$ & $\begin{array}{l}++/ 99 \\
++/ 98 \\
++/ 98\end{array}$ & $\begin{array}{l}++/ 34 \\
++/ 19 \\
++/ 8\end{array}$ \\
\hline
\end{tabular}

$\star_{\text {int }}=$ Intensity of staining: - , no positive cells; + , majority of positive cells staining weakly; ++ , intermediately; +++ , or strongly. $\%=$ Percentage of positive cells of a total of 500 cells. 
Table 3 HLA class II expression and modulation by interferons after 2 days of incubation as determined by immunocytochemistry

\begin{tabular}{|c|c|c|c|c|c|c|}
\hline \multirow[b]{2}{*}{$\begin{array}{l}\text { Treatment } \\
\text { (IU/ml) }\end{array}$} & \multicolumn{3}{|c|}{ Cell line 92-1 } & \multicolumn{3}{|c|}{ Cell line Mel 202} \\
\hline & $\begin{array}{l}H L A-D R \\
\text { int } / \%^{\star}\end{array}$ & $\begin{array}{l}H L A-D Q \\
\text { int } / \%\end{array}$ & $\begin{array}{l}H L A-D P \\
\text { int } / \%\end{array}$ & $\begin{array}{l}H L A-D R \\
\text { int } / \%\end{array}$ & $\begin{array}{l}H L A-D Q \\
\text { int/\% }\end{array}$ & $\begin{array}{l}H L A-D P \\
\text { int } / \%\end{array}$ \\
\hline $\begin{array}{l}\text { Control } \\
\text { rINF- } \alpha 50 \\
\text { rINF- } \alpha 200 \\
\text { rINF- } \alpha 500\end{array}$ & $\begin{array}{l}-10 \\
+/<1 \\
-10 \\
-10\end{array}$ & $\begin{array}{l}-/ 0 \\
-/ 0 \\
-/ 0 \\
-/ 0\end{array}$ & $\begin{array}{l}-/ 0 \\
-/ 0 \\
-/ 0 \\
-/ 0\end{array}$ & $\begin{array}{l}-/ 0 \\
-/ 0 \\
-/ 0 \\
-/ 0\end{array}$ & $\begin{array}{l}\text { NT } \\
\text { NT } \\
\text { NT } \\
\text { NT }\end{array}$ & $\begin{array}{l}\text { NT } \\
\text { NT } \\
\text { NT } \\
\text { NT }\end{array}$ \\
\hline $\begin{array}{l}\text { rINF-g } 50 \\
\text { rINF-g } 200 \\
\text { rINF-g } 500\end{array}$ & $\begin{array}{l}++/ 64 \\
++/ 86 \\
++/ 90\end{array}$ & $\begin{array}{l}+/ 11 \\
+/ 22 \\
+/ 23\end{array}$ & $\begin{array}{l}+/ 10 \\
++/ 77 \\
++/ 85\end{array}$ & $\begin{array}{l}++/ 7 \\
++13 \\
++16\end{array}$ & $\begin{array}{l}\text { NT } \\
\text { NT } \\
\text { NT }\end{array}$ & $\begin{array}{l}\text { NT } \\
\text { NT } \\
\text { NT }\end{array}$ \\
\hline
\end{tabular}

$\star_{\text {int }}=$ intensity of staining: - , no positive cells; + , majority of positive cells staining weakly; ++ , intermediately; +++ , or strongly. $\%=$ Percentage of positive cells of a total of 500 cells. NT $=$ not tested.

(Bw4), and B44 (Bw4). On both cell lines expression of HLA-Bw6 antigens was not observed, neither on untreated nor on IFN- $\alpha$ or IFN- $\gamma$ treated cells, and Mel 202 did not express HLA-A2 antigens (data not shown).

The effects of IFN- $\alpha$ and IFN- $\gamma$ on expression of locus and allele specific HLA antigens

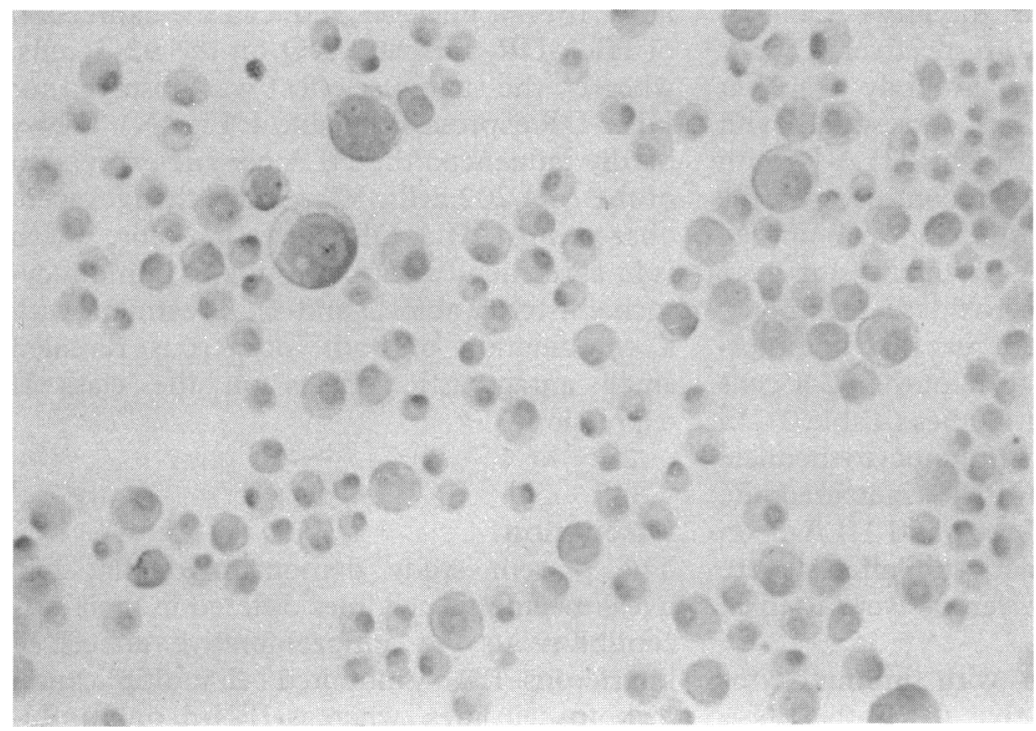

Fig $3 A$

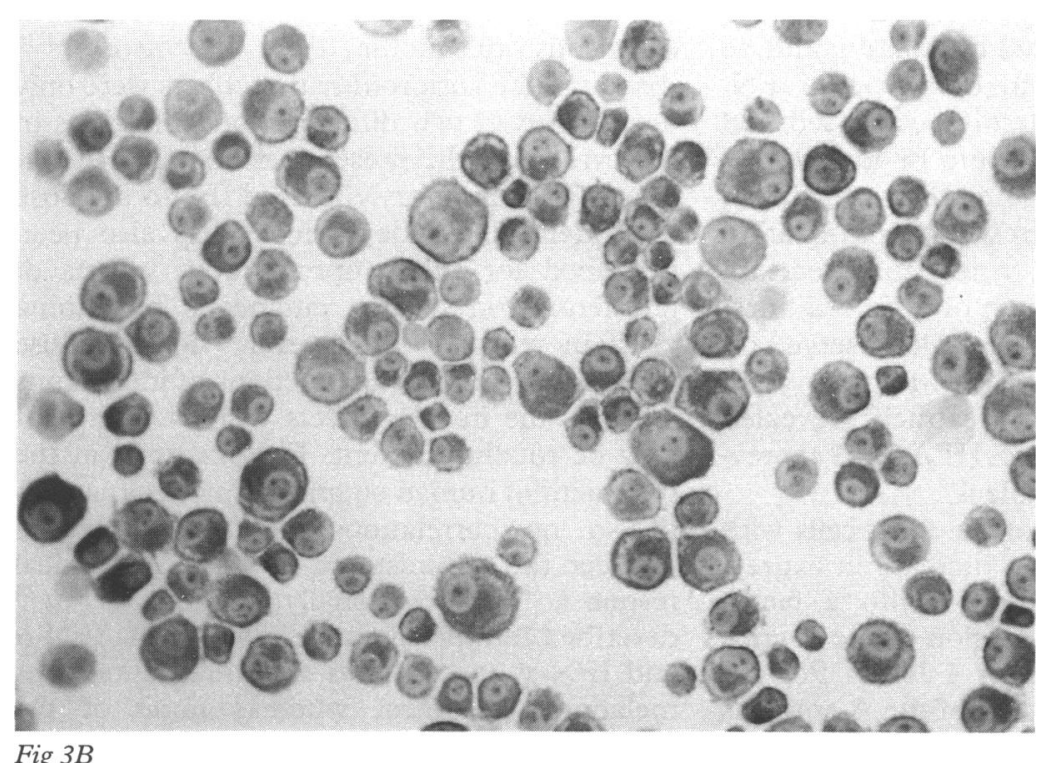

Figure 3 Induction of $H L A-D R$ expression by IFN- $\gamma$ and not by IFN- $\alpha$ (cell line 92-1; immunocytochemistry). (A) The IFN- $\alpha$ treated cells (200 IU/ml for 2 days) are HLA-DR negative. (B) After 2 days of treatment with IFN- $\gamma 86 \%$ of the cells become HLA-DR positive. (Cytospin preparations; original magnification $\times 200$.) after 2 days of incubation are shown in Table 2. Without addition of IFNs, the 92-1 cells showed expression of HLA-A, A3, and HLA-B in high percentages, but incubation with IFN- $\alpha$ as well as with IFN- $\gamma$ led to an increase to $100 \%$ of positive cells or to a higher staining intensity in cases where $100 \%$ of cells were positive already. The untreated 92-1 cells showed only weak staining of HLA-A2 on $69 \%$ of the cells and did not express HLA-Bw4. At their lowest dose, IFN- $\alpha$ and IFN- $\gamma$ increased HLA-A2 expression and induced HLA-Bw4 expression. As shown in Table 2, HLA-B expression on Mel 202 control cells was clearly lower than on 92-1 cells, but expression was also increased by incubation with IFN- $\alpha$ and IFN- $\gamma$. The effects of interferons on HLA-Bw4 expression on the Mel 202 cells were much less pronounced than on $92-1$.

\section{HLA class II expression}

The untreated cells of both cell lines did not express HLA class II antigens. Incubation with IFN- $\alpha$ at various concentrations did not change this. On the other hand, IFN-y induced HLA class II expression on both cell lines already at the lowest concentration (Table 3). However, HLA-DR expression was induced only on a limited number of Mel 202 cells ( $\max 7 \%$ of cells). The increase in HLA class II expression on the 92-1 melanoma cells was more pronounced and was dose dependent (Table 3). Besides HLA-DR expression, HLA-DP and HLA-DQ expression was also determined on the 92-1 cells, and revealed that HLA-DR reached a higher level of expression than HLA-DP and DQ. The effects of IFN- $\alpha$ and IFN- $\gamma$ on HLA-DR expression on the 92-1 cells are shown in Figure 3.

EFFECT OF rIFN- $\alpha$ AND rIFN- $\gamma$ ON ANTIGENETIC PROFILE AS DETERMINED BY FACS ANALYSIS Immunohistology on cytospin preparations revealed strong expression of the monomorphic determinants of the HLA class I antigens and of $\beta_{2}$ microglobulin on $100 \%$ of the cells of both cell lines. However, the already high level of expression of these antigens made it impossible to study the effects of IFN- $\alpha$ or IFN- $\gamma$ on these molecules. In order to determine the effects of interferons in a more quantitative manner than is possible with cytochemistry, we therefore performed FACS analysis additionally. This technique might also make it possible to determine synergistic or antagonistic effects of interferons on expression of cell surface antigens.

\section{HLA class I expression}

The untreated cells of the two different cell lines showed differences in the level of expression of the monomorphic HLA class I determinants, with the highest levels of expression observed for the 92-1 cell line (Table 4). Two days of treatment with IFN- $\alpha$ and IFN- $\gamma$ at a concentration of $200 \mathrm{IU} / \mathrm{ml}$ significantly enhanced the expression of the 
Table 4 HLA class I and II expression in untreated and interferon treated uveal melanoma cell lines as determined by FACS analysis

\begin{tabular}{|c|c|c|c|c|c|c|c|c|}
\hline & \multicolumn{4}{|c|}{ Cell line 92-1 (mFI (SEM)) † } & \multicolumn{4}{|c|}{ Cell line Mel $202(m F I(S E M)) \dagger$} \\
\hline & Control & $I F N-\alpha$ & $I F N-\gamma$ & $\begin{array}{l}\text { IFN- } \alpha+ \\
\text { IFN- } \gamma\end{array}$ & Control & $I F N-\alpha$ & $I F N-\gamma$ & $\begin{array}{l}I F N-\alpha+ \\
I F N-\gamma\end{array}$ \\
\hline $\begin{array}{l}\text { HLA-ABC } \\
\beta_{2} \text { microgl } \\
\text { HLA-A } \\
\text { HLA-B } \\
\text { HLA-A2 } \\
\text { HLA-A3 } \\
\text { HLA-Bw4 } \\
\text { HLA-DR } \\
\text { HLA-DP } \\
\text { HLA-DQ }\end{array}$ & $\begin{array}{r}17.1(0.2) \\
91.0(1.6) \\
2.7(0.1) \\
2.3(0.2) \\
106.9(0.9) \\
72.7(1.9) \\
2.0(0.2) \\
0.1(0.6) \\
0.5(0.8) \\
0.3(0.6)\end{array}$ & $\begin{array}{r}38 \cdot 0(0 \cdot 2) \\
210 \cdot 6(2 \cdot 1) \\
9 \cdot 0(0 \cdot 3) \\
15 \cdot 1(1 \cdot 1) \\
227 \cdot 2(2 \cdot 2) \\
120 \cdot 3(2 \cdot 5) \\
9 \cdot 5(0 \cdot 1) \\
0 \cdot 3(1 \cdot 2) \\
-0 \cdot 3(0 \cdot 8) \\
-0.3(0 \cdot 8)\end{array}$ & $\begin{array}{r}37.9(0.2) \\
264.8(3.7) \\
4.9(0.2) \\
12.2(3.2) \\
149.3(1.1) \\
105.6(3.6) \\
12.0(0.3) \\
11.8(3.6) \\
3.5(1.3) \\
2.2(0.5)\end{array}$ & $\begin{array}{r}40.2(0.2) \\
266.3(2.8) \\
8.8(1.0) \\
12.5(0.2) \\
158.4(1.8) \\
136.9(2.1) \\
7.0(0.4) \\
10.5(1.5) \\
0.1(1.3) \\
0.2(1.3)\end{array}$ & $\begin{array}{r}8.5(0.1) \\
38.4(1.8) \\
2.8(0.7) \\
0.6(0.5) \\
0.1(0.8) \\
13.3(0.9) \\
0.4(0.1) \\
-0.5(0.6) \\
0.3(0.8) \\
-0.6(0.6)\end{array}$ & $\begin{array}{r}21.3(0.1) \\
49.3(1.8) \\
6.9(1.1) \\
2.1(0.4) \\
-0.6(0.2) \\
29.9(0.9) \\
0.5(0.1) \\
-0.3(0.3) \\
-0.3(0.2) \\
0.4(0.7)\end{array}$ & $\begin{array}{r}33.2(0.5) \\
78.7(2.9) \\
5.0(1.2) \\
3.4(1.9) \\
0.2(0.1) \\
32.5(0.9) \\
2.3(0.3) \\
1.7(1.3) \\
0.3(0.9) \\
1.2(0.6)\end{array}$ & $\begin{array}{r}37.4(0.6) \\
87.9(2.7) \\
3.6(1.3) \\
3.0(1.3) \\
0.1(1.8) \\
38.0(1.8) \\
3.4(0.5) \\
-1.5(1.2) \\
-1.7(1.2) \\
-0.7(1.5)\end{array}$ \\
\hline
\end{tabular}

*Cells were incubated with control medium or $200 \mathrm{IU} / \mathrm{ml}$ IFN- $\alpha$ and IFN- $\gamma$, alone or in combination, for 48 hours.

†Data are expressed as mean fluorescence of two independent measurements after subtraction of background fluorescence (SEM).

monomorphic determinants of the HLA class I molecules on both cell lines (Table 4; Fig 4A-D). Treatment with a combination of both interferons revealed small synergistic effects (Table 4).

The untreated cells of both cell lines showed only little fluorescence with the monoclonal antibodies directed against the HLA-A and Blocus (HCA2 and $\mathrm{HC10}$, respectively), when compared with the control antibody (Table 4; Fig $4 \mathrm{E}-\mathrm{H})$. These findings correspond with the results obtained with anti-HLA-B with regard to Mel 202, but are in contrast with the outcome of the HLA-A staining on both cell lines and with the HLA-B staining on 92-1 cells with the immunoperoxidase technique. The latter technique had revealed an intermediate staining of $99-100 \%$ of the $92-1$ cells with both monoclonal antibodies (Table 2). In agreement with the immunocytochemical study, both IFN- $\alpha$ and IFN- $\gamma$ increased the level of expression of HLA-A and HLA-B on both cell lines. No synergistic effects were observed when both interferons were used in combination.

In a similar way as with immunocytochemistry, we observed that (1) both IFN- $\alpha$ and IFN- $\gamma$ increased the level of expression of HLA-A2 on the 92-1 cells and that the other cell line did not carry HLA-A2, (2) HLA-A3 was expressed on both cell lines and could be enhanced by treatment with both types of IFN, (3) HLA-Bw4 was hardly expressed on untreated 92-1 cells and could be induced by treatment with both IFN- $\alpha$ or IFN- $\gamma$ (Table 4; Fig 4I and 4J). Treatment with a combination of both interferons led to synergistic effects on HLA-A3 antigen expression of both cell lines. Small synergistic effects were also observed on HLA-Bw4 expression of the Mel 202 cells, whereas combined IFN treatment revealed small antagonistic effects on HLA-Bw4 expression of the 92-1 cells (Table 4).

In general, treatment of the 92-1 cells with IFN- $\alpha$ or IFN- $\gamma$ led to an increase in expression of the HLA-A antigens with a factor 1.4-3.3, whereas the expression of the $B$ antigens increased with a factor $4 \cdot 7-6 \cdot 6$. For the Mel 202 cells the expression of the A antigens increased with a factor $1 \cdot 3-2 \cdot 9$, whereas it is difficult to determine factors of enhancement of the HLA-B antigens, since the untreated cells showed hardly any expression of $B$ antigens (Table 4).

\section{$H L A$ class II expression}

In agreement with immunocytochemistry, FACS analysis revealed no expression of the HLA class II antigens on the untreated cells of both cell lines. Two days of treatment with IFN- $\alpha$ at a concentration of $200 \mathrm{IU} / \mathrm{ml}$ could not induce class II expression on these cell lines. IFN- $\gamma$, however, induced the expression of HLA-DR, DP, and DQ on the 92-1 cells, whereby the strongest effect was observed for HLA-DR expression (Table 4; Fig 4N). IFN- $\gamma$ hardly influenced the HLA class II expression of the Mel 202 cells. Very small changes were observed for HLA-DR expression only, which is in agreement with the results of immunocytochemistry (Tables 3 and 4). Treatment with a combination of both interferons revealed small antagonistic effects on the class II expression.

\section{Discussion}

The present study demonstrated that two uveal melanoma cell lines differed in their susceptibility to the antiproliferative effects of interferons. IFN- $\gamma$ inhibited cell multiplication of both cell lines, whereas IFN- $\alpha$ only influenced the proliferation of the 92-1 cell line. These findings are in agreement with the reported effect of IFN- $\alpha$ and IFN- $\gamma$ on human cutaneous melanoma cells in vitro. 183435 Although the antiproliferative effects were only determined at two different concentrations of the cytokines, the present results suggest that the growth inhibitory effects of IFN- $\alpha$ are dose dependent. Dose dependency has also been described for the antiproliferative effects of interferons on human cutaneous melanoma cells in vitro. ${ }^{1835}$ However, despite dose related growth inhibitory actions of interferons in vitro, the in vivo effects of IFN treatment may be totally different. For example, in the treatment of human cutaneous melanoma with IFN- $\alpha$ no correlations could be observed between the administered dose and the clinical response. ${ }^{36} 37$ Additionally, Osanto et al $^{34}$ described antiproliferative effects of IFN- $\alpha$ and IFN- $\gamma$ on cell lines of human cutaneous melanoma in vitro, whereas none of the patients from whom the cell lines were derived responded to in vivo IFN treatment. From these data Osanto et $a l^{34}$ deduced that other actions, like immunomodulation, might be more relevant in the induction of tumour 


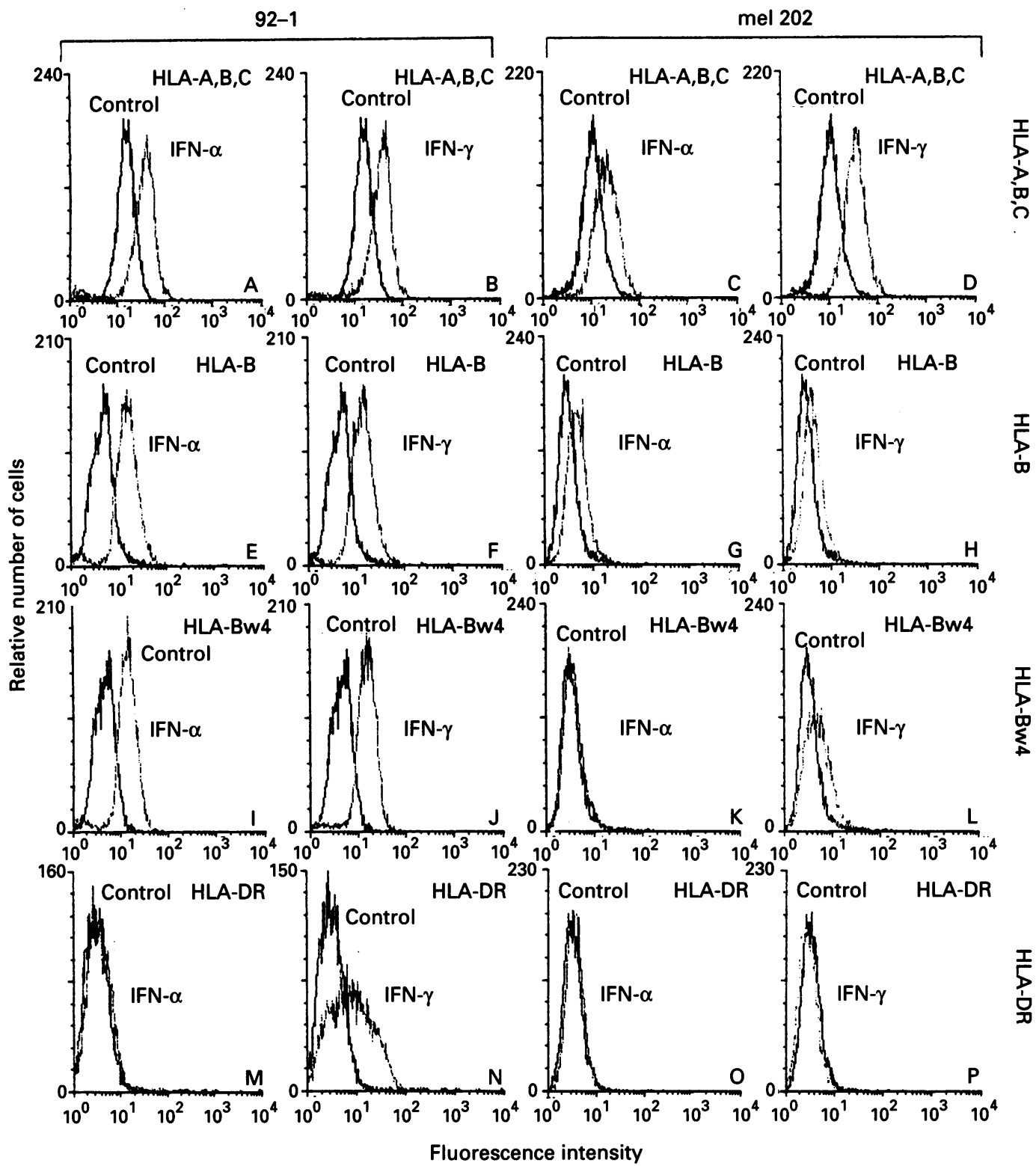

Figure 4 Effects of expression of various antigens on human uveal melanoma cells in vitro after incubation for 48 hours with $200 \mathrm{IU} / \mathrm{ml}$ IFN- $\alpha$ or IFN- $\gamma$ (FACS analysis). Enhancement of monomorphic HLA class I expression by IFN- $\alpha$ and IFN- $\gamma$ on both cell lines $(A-D)$. Enhancement of $H L A-B$ expression by IFN- $\alpha$ and IFN- $\gamma$ on both cell lines (E-H). Enhancement of HLA-Bw4 expression by IFN- $\alpha$ and IFN- $\gamma$ on cell line 92-1 (I and $)$ ). HLA-Bw4 expression on cell line 202 was only enhanced by IFN- $\gamma$ (K and $L$ ). IFN- $\alpha$ had no effect on $H L A-D R$ expression, whereas IFN- $\gamma$ induced $H L A-D R$ expression on the $92-1$ cells $(M-P)$.

regression than the antiproliferative effects. We, therefore, not only studied the effect of IFN- $\alpha$ and IFN- $\gamma$ on proliferation, but also the modulation of antigen expression on uveal melanoma cells, specifically of the HLA class I and II antigens.

In order to determine changes in expression after IFN treatment at different concentrations, an indirect immunoperoxidase technique on cytospin preparations was used. An advantage of this technique is the visualisation of antigen expression, but with this technique it is difficult to determine small changes in staining intensity. For example, the already high level of expression of the monomorphic determinants of the HLA class I antigens on cytospin preparations of uveal melanoma cells made it impossible to study the effects of IFN- $\alpha$ or IFN- $\gamma$ on these molecules. We therefore also performed FACS analysis which, in addition, made it possible to determine synergistic or antagonistic effects of interferons on expression of cell surface antigens. Although it is difficult to compare the results of the two techniques in a quantitative manner, the overall results of both techniques were in good agreement.

With regard to the monomorphic HLA class I antigens, both IFN- $\alpha$ and IFN- $\gamma$ significantly enhanced the expression of these molecules, with IFN- $\gamma$ being the most potent inducer. These findings are in agreement with previous reports concerning different types of tumours. ${ }^{1418}$ The small synergistic effects of combined cytokine treatment are possibly due to the induction of cytokine receptors on the tumour cells. ${ }^{38}$

Since allele specific binding of tumour specific antigens has been reported for cutaneous melanoma, for example, ${ }^{7-9}$ allele specific modulation of antigen expression might be important in the development of effective antimelanoma immune responses in vivo. We therefore not only investigated the effects of 
interferons on monomorphic HLA class I antigens, but also on different locus and allele specific HLA class I antigens. With regard to the 92-1 cells, treatment with IFN- $\alpha$ and IFN- $\gamma$ increased the expression of both the HLA-A and B antigens, whereby the effects on the HLA-B antigens were stronger than on the HLA-A antigens. This phenomenon has been reported for human cutaneous melanoma cells as well. ${ }^{39}$ Similar results were shown for the Mel 202 cells. The fact that HLA-A2 expression on Mel 202 cells could not be induced with cytokine treatment is most probably due to the genetical absence of this allele. However, since the patient was not available for HLA typing, we could not test this hypothesis. Application of the two cytokines together led in some cases to small synergistic effects and in others to small antagonistic effects, with differences between the two cell lines. The significance of these findings is unclear, but makes it difficult to give clinical recommendations.

Expression of HLA class II antigens was not induced by IFN- $\alpha$ on either of the cell lines. On the other hand, IFN- $\gamma$ did induce expression of class II on both cell lines, although only very small effects were observed for HLA class II antigens on the Mel 202 cells. Similar results were reported for cutaneous melanoma and several other types of tumours. ${ }^{15} 18$ However, Giacomini et al ${ }^{40}$ reported that IFN- $\alpha$ could induce class II expression on cutaneous melanoma cells as well, but that IFN- $\gamma$ is a much more potent inducer of class II expression. Although the exact mechanisms by which cytokines induce the expression of surface antigens are unknown, it has already been shown, for cutaneous melanoma, that IFN- $\gamma$ requires de novo protein synthesis, while IFN- $\alpha$ does not, ${ }^{41}$ which might also be an explanation for the differential effects of IFN- $\alpha$ and IFN- $\gamma$ on the uveal melanoma cells. The strongest effects of IFN- $\gamma$ on class II expression were observed for the HLA-DR antigens. This is in agreement with previous reports on cutaneous melanoma. ${ }^{17} 42-44$ The reasons for the antagonistic effects of combined IFN treatment on class II expression are unknown. With respect to the susceptibility of the melanoma cells to modulation of HLA antigen expression in general, differences were observed between the two different cell lines. This might reflect potential individual differences in responsiveness to treatment with interferons in vivo.

The authors thank Dr J G A Houbiers and Ms $S$ van der Burg (Immunohematology and Bloodbank, Leiden, the Netherlands) for kindly supplying the monoclonal antibodies directed against the monomorphic and allele specific HLA antigens. We are also grateful to Dr H L Ploegh (the Netherlands Cancer Institute) for providing the monoclonal antibodies HC10 and HCA2. We providing the monoclonal antibodies $\mathrm{HClO}$ and HCA2. We thank $M$ s $G$ Bouma for her assistance in the proliferation assay
and $M$ van der Keur for his assistance in the FACS experiments.

1 Talpaz M, Kantariian HM, McCredie K, Trujillo JM Keating MJ, Gutterman JU. Hematologic remission and cytogenetic improvement induced by recombinant interferon alfa $\mathrm{A}$ in chronic myelogenous leukemia. $N$ Engl $f$ Med 1986; 314: 1065-9.

2 Colomb HM, Fefer A, Golde DW, Ozer H, Portlock C, Silber R, et al. Report of a multi-institutional study of 193 patients with hairy cell leukemia treated with interferon alfa-2b. Semin Oncol 1988; 15: 7-9.

3 Clark RH, Dimitrov NV, Axelson JA, Charamella LJ, Stott PB. A phase II trial of intermittent leukocyte interferon and high dose chlorambucil in the treatment of
non-Hodgkin's lymphoma resistant to conventional therapy. Am $\mathcal{F}$ Clin Oncol 1989; 12: 75-7.

4 Kirkwood JM, Ernstoff MS. Role of interferons in the therapy of melanoma. F Invest Dermatol 1990; 95: 180-4S

5 McLeod GR, Thomson DB, Hersey P. Clinical evaluation of interferons in malignant melanoma. $\mathcal{f}$ Invest Dermato 1990; 95: 185S-7S.

6 Murray JL, Rosenblum MG. Modulation of melanoma antigens by interferons. Cancer Treat Res 1991; 54: 153-67.

7 Wölfel T, Klehmann E, Müller CA, Schütt KH, Meyer zum Büschenfelde KH, Knuth A. Lysis of human melanoma cells by autologous cytolytic $\mathrm{T}$ cell clones. Identification of human histocompatibility leukocyte antigen A2 as a of human histocompatibility leukocyte antigen $\mathrm{A} 2$ as a restriction element for

8 Crowly NJ, Darrow TL, Quinn-Allen MA, Seigler HF. MHC-restricted recognition of autologous melanoma by tumour-specific cytotoxic T-cells - evidence for restriction by a dominant HLA-A allele. F Immunol 1991; 146: 1692-9.

9 Traversari C, Van der Bruggen P, Luescher IF, Lurquin C, Chomez P, Van Pel A, et al. A nonapeptide encoded by human gene MAGE-1 is recognized on HLA-A1 by cytolytic T-lymphocytes directed against tumor antigencytolytic T-lymphocytes directed against

10 Jager MJ, Waard-Siebinga I de, Kool J. Allele-specific HLAexpression on uveal melanoma. Invest Ophthalmol Vis Sci 1993; 34 (suppl): 890.

11 Clemens MJ, McNurlan MA. Regulation of cell proliferation and differentiation by interferons. Biochem $\mathcal{F} 1985$ 226: 345-60.

12 Fischer PB, Grant S. Effects of interferon on differentiation of normal and tumor cells. Pharmacol Ther 1985; 27: 143-66.

13 Munker M, Munker R, Saxton RE, Koeffler HP. Effect of recombinant monokines, lymphokines, and other agents on clonal proliferation of human lung cancer cell lines. on clonal proliferation of hum

14 Detrick B, Evans CH, Chader G, Percopo CM, Hooks JJ. Cytokine-induced modulation of cellular proteins in retinoblastoma. Invest Ophthalmol Vis Sci 1991; 32 1714-22.

15 Carrel S, Schmidt-Kessen A, Giuffrè L. Recombinant interferon- $\gamma$ can induce the expression of HLA-DR and DC on DR-negative melanoma cell and enhance the expression of $\mathrm{HLA}-\mathrm{ABC}$ and tumor-associated antigens. Eur $\mathcal{F}$ Immunol 1985; 15: 118-23.

16 Nisticò $P$, Tecce R, Giacomini P, Cavallari A, D'Agnano I Fisher PB, et al. Effect of recombinant human leukocyte, fibroblast and immune interferons on expression of class I and II major histocompatibility complex and invariant chain in early passage human melanoma cells. Cancer Res 1990; 50: 7422-9.

17 Garbe C, Krasagakis K, Zouboulis CC, Schröder K, Krüger $\mathrm{S}$, Stadler R, et al. Antitumor activities of interferon alfa, beta, and gamma and their combinations on human melanoma cells in vitro: changes of proliferation, melanin synthesis, and immunophenotype. F Invest Dermatol 1990; 95: $231-7 \mathrm{~S}$.

18 Garbe C, Krasagakis K. Effects of interferons and cytokines on melanoma cells. 7 Invest Dermatol 1993; 100: 239-44S

19 Ksander BR, Rubsamen PE, Olsen KR, Cousins SW, Streilein JW. Studies of tumor-infiltrating lymphocytes from a human choroidal melanoma. Invest Ophthalmol $V i$ Sci 1991; 32: 3198-208.

20 Waard-Siebinga I de, Blom D-JR, Griffioen M, Schrier PI Hoogendoorn E, Beverstock G, et al. Establishment and characterization of an uveal-melanoma cell line. Int $f$ Cancer 1995; 62: 155-61.

21 Bruning JW, Kardol MJ. Nonradioactive quantitation of lymphocyte proliferation in the culture tray. PHAstimulation, MLC and PLT. Hum Immunol 1983; 8: 305-6.

22 Schanz U, Roelen DL, Bruning JW, Kardol MJ, van Rood JJ Claas FHJ. The relative radioresistance of interleukin-2 production of human peripheral blood lymphocytes: consequences for the development of a new limiting dilution assay for the enumeration of helper $\mathrm{T}$ lymphocyte precursor frequencies. F Immunol Methods 1994; 169: 221-30.

23 Barnstable CJ, Bodmer WF, Brown G, Galfre G, Milstein $\mathrm{C}$, Williams AF, et al. Production of monoclonal antibodies to group A erythrocytes, HLA and other human cell surface antigens - new tools for genetic analysis. Cell 1978; 14: 9-20.

24 Brodsky FM, Bodmer WF, Parham P. Characterization of monoclonal anti- $\beta_{2}$-microglobulin antibody and its use in the genetic and biochemical analysis of major histocomthe genetic and biochemical analysis of major histoco

25 Stam NJ, Vroom ThM, Peters PJ, Pastoors EB, Ploegh HL. HLA-A- and HLA-B-specific monoclonal antibodies reactive with free heavy chains in western blots, in formalin-fixed, paraffin-embedded tissue sections and in cryoimmunoelectron microscopy. Int Immunol 1990; 2: 113-25.

26 Stam NJ, Spits H, Ploegh HL. Monoclonal antibodies raised against denaturated HLA-B locus heavy chains permit biochemical characterization of certain HLA-C locus products. F Immunol 1986; 137: 2299-306.

27 Parham P, Brodsky FM, Partial purification and some properties of BB7.2. Human Immunol 1981; 3: 277-99. properties of BB7.2. Human Immunol 1981; 3: 277-99. HLA-A3. Hybridoma 1982; 1: 87-90.

29 Radka SF, Kostyu DD, Amos DB. A monoclonal antibody directed against the HLA-Bw6 epitope. F Immunol 1982; 128: $2804-6$. 
30 Rebai N, Malissen B, Pierres M, Accolla RS, Corte G, Mawas C. Distinct HLA-DR epitopes and distinct families of HLA-DR molecules defined by 15 monoclonal antibodies (mAb) either anti-DR or allo-anti $\mathbf{l}^{\mathrm{k}}$ crossantibodies (mAb) either anti-DR or allo-anti la ${ }^{k}$ cross-
reacting with human DR molecule. I. Cross-inhibition reacting with human DR molecule. I. Cross-inhibition
studies of $\mathrm{mAb}$ cell surface fixation and differential binding of $\mathrm{mAb}$ to detergent-solubilized HLA molecules immobilized to a solid sphase by a first mAb. Eur $f$ Immunol 1983; 13: 106-11.

31 Spits H, Borst J, Giphart M, Coligan J, Terhorst C, De Vries JE. HLA-DC antigens can serve as recognition elements for human cytotoxic T lymphocytes. Eur $₹$ Immuno 1984; 14: 299-304.

32 Watson AJ, DeMars R, Trowbridge IS, Bach FH. Detection of a novel human class II HLA antigen. Nature 1983; 304: 358-61.

33 Ledbetter JA, Evans RL, Lipinnski M, Cunningham-Rundles C, Good RA, Herzenberg LA. Evolutionary conservation of Good RA, Herzenberg LA. Evolutionary conservation of surface molecules that distinguish $T$ lymphocyte in mouse and man. $\mathcal{E} \operatorname{Exp} M e d$ 1981; 153: 310-23.

34 Osanto S, Jansen R, Naipal AMIH, Gratama JW, van Leeuwen A, Cleton FJ. In vivo effects of combination treatment with recombinant interferon-gamma and alfa in metastatic melanoma. Int 7 Cancer 1989 ; 43 1001-6.

35 Tyring SK, Klimpel G, Brusk M, Gupta V, Stanton GJ, Fleischmann Jr WR, et al. Eradication of cultured human melanoma cells by immune interferon and leukocytes. $\mathcal{f}$ melanoma cells by immune interfer

36 Goldberg RM, Ayoob M, Silgals R, Ahlgran JD, Neefe JR. Phase-II trial of lymphoblastoid interferon in metastatic malignant melanoma. Cancer Treat Rep 1985; 69: 813-6.

37 Goldstein D, Laslo J. Interferon therapy in cancer: from imagion to interferon. Cancer Res 1986; 46: 4315-29.

38 Ishii $Y$, Tsukagoshi S. Synergistic effect of human recombinant interferon-alfa $2 \mathrm{a}$ in combination with interferongamma and the induction of interferon-alfa $2 \mathrm{a}$ receptor by interferon-gamma. f Pharmacobiodyn 1989; 12: 299-304.

39 Osanto S, Jansen R, Vloemans $M$. Downmodulation of c-myc expression by inteferon gamma and tumour necrosis factor alfa precedes growth arrest in human melanoma cells. Eur f Cancer 1992; 28: 1622-7.

40 Giacomini P, Gambari R, Barbieri R, Nistico P, Tecce $R$, Pestka $S$, et al. Regulation of the antigenic phenotype of human melanoma cells by recombinant interferons. Anticancer Res 1986; 6: 877-84.

41 Giacomini P, Tecce R, Gambari R, Sacchi A, Fisher PB, Natali PG. Recombinant human IFN- $\alpha$, but not IFN- $\alpha$ or Natal PG. Recombinant human IFN- $\gamma$, but not IFN- $\alpha$ or
IFN- $\beta$, enhances MHC- and non-MHC-encoded glycoproteins by a protein synthesis-dependent mechanism. f Immunol 1988; 140: 3073-81.

42 Maio M, Gulwani B, Langer JA, Kerbel RS, Duigou GJ, Fisher PB, et al. Modulation by interferons of HLA antigen, high-molecular-weight melanoma associated antigen, and intercellular adhesion molecule 1 expression by cultured melanoma cells with different metastatic potential. Cancer Res 1989; 49: 2980-7.

43 Anichini A, Mortarini R, Fossati G, Parmiani G. Phenotypic profile of clones from early cultures of human metastatic melanomas and its modulation by recombinant metastatic melanomas and its modulation by recomb

44 Taramelli D, Fossati G, Mazzocchi A, Delia D, Ferrone S Parmiani G. Classes I and II HLA and melanoma-associated antigen expression and modulation on melanoma cells isolated from primary and metastatic lesions. Cancer Res 1986; 46: 433 . 